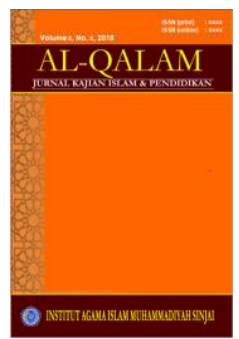

Volume 9, No. 1, 2017

ISSN (print) : 1858-4152

ISSN (online) : xxxx-xxxx

Homepage : http://journal.iaimsinjai.ac.id/index.php/al-qalam

\title{
PENDEKATAN PEMBELAJARAN DARI BERBASIS ICT KE DI ERA BIG DATA, REORIENTASI PEMBELAJARAN PAI DALAM PARADIGMA KONSTRUKTIVISME
}

\author{
Oleh: Umar ${ }^{1}$
}

$$
* * *
$$

\begin{abstract}
Abstrak
Tulisan ini mendeskripsikan tentang pandangan-pandangan empiris yang bersifat umum terkait pendekatan pembelajaran berbasis digitalisasi di era ICT dan Big Data serta reorientasi pembelajaran PAI dalam paradigma konstruktivisme. Metode pengumpulan data dalam penulisan ini dilakukan dari berbagai sumber literatur yang relevan dalam diskursus dan memperkaya khazanah pembelajaran khususnya PAI. Pendekatan pembelajaran berbasis ICT selama ini telah menopang efektifitas pembelajaran disatu sisi pemanfaatannya bahkan belum optimal. Kini dengan lahirnya inivasi baru era Big Data menawarkan tantangan baru bagi kalangan pendidik dan pelajar untuk memanfaatkan ketersediaan data dan ragam informasi. Maka peran pembelajaran yang beparadigma konstruktivis akan mampu mengakomodasi tantangan ini, sebab pada prinsipnya pembelajaran adalah menemukan dan membentuk makna-makna baru.
\end{abstract}

Kata Kunci: Pendekatan berbasis ICT dan Era Big Data, Pembelajaran PAI, Paradigma Konstruktivisme

\section{PENDAHULUAN}

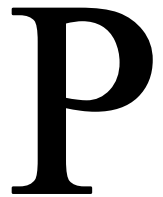
endidikan Agama Islam yang dinilai sangat memberikan sumbangsih dalam pembentukan nilai-nilai kehidupan sesuai prinsip dasar ajaran Islam. Pembelajaran inimerupakan usaha pembelajaran yang dilakukan secara sistematis serta berkelanjutan untuk mengembangkan potensi intelektual, keterampilan dan sikap seseorang. PP No.19 tahun 2005 ayat 1 menegaskan proses pembelajaran pada satuan pendidikan diselenggarakan secara interaktif,

${ }^{1}$ Dosen Tetap Institut Agama Islam Muhammadiyah Sinjai 


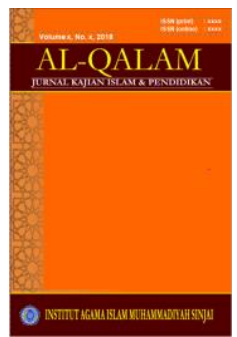

AL-QALAM

Jurnal Kajian Islam \& Pendidikan

Volume 9, No. 1, 2017

ISSN (print) : 1858-4152

ISSN (online) : xxxx-xxxx

Homepage : http://journal.iaimsinjai.ac.id/index.php/al-qalam

inspiratif, menyenangkan, menantang, memotivasi peserta didik untuk berpartisipasi aktif, serta memberikan ruang yang cukup bagi prakarsa, kreatifitas, sesuai dengan bakat, minat dan perkembangan fisik serta psikologis peserta didik.

Hal tersebut melibatkan tata cara pembelajaran dengan metodologi, teknik, strategi dan media pembelajaran yang digunakan secara efektif agar pembelajaran berhasil optimal. Disamping pembelajaran secara metodologis, peran lingkungan secara dimensial dan terbuka (Open Learning Environtmens) seperti digitalisasi berbasis ICT internet turut mempengaruhi kehidupan nyata peserta didik yakni dengan berbagai layanan sosial media. Website Kemkominfo RI 2014 memberitakan dan Asosiasi Pengguna Jasa Internet Indonesia (APJII) tahun 2016 merilis $^{2}$ pengguna internet ini sangat pesat dikalangan masyarakat. Data ini menunjukkan bahwa pengguna internet dan media sosial sangat diminati tak terkecuali kalangan siswa dalam akses informasi dan interaksi komunikasi pada berbagai hal bahkan pemanfaatanya lebih pada bukan tatanan fungsi yang semestinya.

Lajunya penemuan (discovery)dalam IPTEK pada berbagai bidang khususnya yang berbasis pendidikanmenopang terciptanya kenyamanan dan kemudahan aktivitas pembelajaran beberapa tahun terakhir dengan berbagai kecanggihan tekhnologi pembelajaran. Inovasi-inovasi teknologi ini terus berkembang dalam upaya memenuhi kebutuhan informasi bagi kalangan educatedandlearner. Dari ICT yang fenomenal kini muncul inovasi baru yang memerlukan respon pengguna informasi oleh kalangan ilmuan menyebutnya sebagai “Inovasi Big Data”.

\footnotetext{
${ }^{2}$ Sebagaimana lembaga riset pasar e-Marketer, populasi netter di Indonesia mencapai 83,7 juta orang pada 2014. Pada tahun 2017, e-Marketer memperkirakan netter Indonesia bakal mencapai 112 juta orang. Lihat Pengguna Internet Indonesia Nomor Enam Dunia, dalam website https://kominfo.go.id/, diakses 6/10/2017. Sedangkan laporan hasil survey (APJII) tahun 2016 pengguna internet menyimpulkan 132,7 juta orang Indonesia telah terhubung ke internet. Konten sosial media yang paling sering dikunjungi yaituFacebook sebanyak 54\% atau 71,6 juta, Istagram $15 \%$ atau 19,9 juta, Youtube 11\% 14,5 juta, Google+ 6\% atau 7,9 juta, Tweeter 5,5\% atau 7,2 juta, Linkedin 0,6\% atau 796 ribu. Lihat Data APJII dalam,Infografis, Penetrasi dan Prilaku Pengguna Internet Indonesia, (APJII) Survey 2016, dalam file pdf, hal. 25.
} 


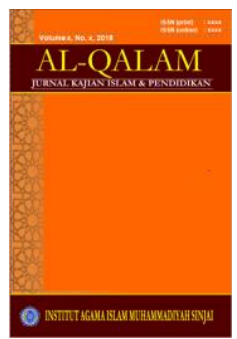

Memasuki era "big data" atau data besar, era dimana terjadi pertumbuhan jumlah data secara eksponensial sebagai imbas dari pesatnya perkembangan teknologi. Dunia semakin terhubung melalui berbagai jenis perangkat digital, sekitar 60 persen perangkat saat ini terubung internet (internet-enabled) yang dikenal dengan istilah Internet of Things (IoT), yang dapat menghasilkan dan membagi data secara langsung. ${ }^{3}$ Pertumbuhan data yang membengkak ini mendapat respon para ilmuan mengembangkan inovasi perangkat yang dapat memproses data dalam jumlah yang besar, perangkat inilah yang akan mengolah dari berbagai sumber dan variasi data berbeda sehingga dapat menghasilkan informasi cepat dan akurat. $^{4}$ Disuatu kesempatan penulis secara sekilas mendengar pemaparan materi dari seorang narasumber yang menginformasikan rilis Forbes tahun 2016 bahwa "data yang dihasilkan dalam dua tahu terakhir sama dengan data yang dihasilkan oleh sejarah ummat manusia." Sebagai inovasi terbaru teknologi, era Big Data telah menjadi era baru dalam dunia pendidikan saat ini, bahkan TIC sebelum era Big Data ini belum dimanfaatkan secara optimal dalam skema pembelajaran.

Pemanfaatan ICT sebagai instrumen penting dan menunjang proses pembelajaran seperti media interaktif, website dll yang dalam dekade terakhir sulit dipisahkan dalam kehidupan individu (learner). Dinilai banyak pihak pemanfaatannya dalam pembelajaran PAI ini masih cenderung parsial yakni dalam membangun pembelajaran bermakna (konstruktif) padahal banyak digunakan secara luas oleh kalangan pendidik dan siswa dalam akses informasi komunikasi. Terlebih diera Big Data yang menawarkan ketersediaan data dan informasi tak terkira.

${ }^{3}$ Saida Ulfa dan Deddy B. Lasfeto,Pendidikan di Era Big Data, (2017), dalam website http://timorexpress. fajar.co.id/2017/05/05/, diakses 6/10/2017.

${ }^{4}$ Contoh perusahaan penyelenggara Big Data Analytics, antara lain Google, IBM, Oracle, Teradata, SAP, dan di Indonesia kita memiliki i-811 dengan produk Paques Big Data Processing \& Analytics. Lebih lanjut lihat, Ine, Era Big Data dan Era Inovasi, 2017 Lihat https://beritabigdata.wordpress.com/ diakses, 10/6/2017. 


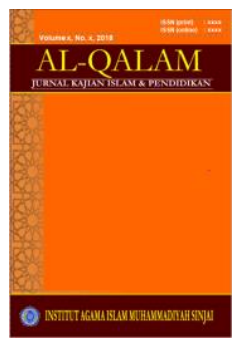

AL-QALAM

Jurnal Kajian Islam \& Pendidikan

Volume 9, No. 1, 2017

ISSN (print) : 1858-4152

ISSN (online) : $\mathrm{xxxx}-\mathrm{xxxx}$

Homepage : http://journal.iaimsinjai.ac.id/index.php/al-qalam

Kaitan tersebut sesuai pandangan dan gagasan Duffy \& Jonassen, (2013) dalam Praherdhiono, (2017) model konseptual lingkungan belajar untuk teknologi ConstructivistLearning Environments (CLEs) melibatkan pebelajardalam menyelidiki masalah, mengkritisi kasus terkait, meninjau sumberinformasi, mengembangkan keterampilan yang diperlukan, berkolaborasi denganorang lain dan penggunaan dukungan sosial dalam pelaksanaan pengalamanbelajar. Lebih lanjut Praherdhiono menilai bahwa pembelajaran dalam konteks ini pengajar (dan bahkan siswa) mesti rela mengakui dan mengalihkan praktek pembelajaran kekonstruktivisme sebagai suatu paradigma baru yang berbasis web ${ }^{5}$, sosial media bahkan Big Data. Maka Miarso (2007) menyarankan para guru harus diyakinkan terlebih dahulu akan kegunaan tekhnologi itu dan bahwa tekhnologi tidak akan menggantikan kedudukannya sebagai guru, melainkan membantu untuk paling tidak menyimpang dan menyajikan konsep, prinsip dan prosedur yang ingin diajarkan. Untuk itu peran guru harus ditingkatkan rasa percaya diri, serta dilibatkan dan ikut berpartisipasi dalam pengembangannya. ${ }^{6}$ Tulisan ini diharapkan dapat memberikaninformasi kepada segenap khalayak dalam rangka optimalisasi pembelajaran PAI dari berbasis media digitaliasi ICT menuju pada inovasi teknologi era Big Data sekaligus ditinjau dalam paradigma konstruktifisme mengingat berbagai dinamika dan polemik dalam pembelajaran banyak menuai kekosongan ruang dan ketertinggalan yang perlu mendapat respon khususnya pembelajaran PAI dimasa kini.

\section{METODE PENELITIAN}

Jenis dan pendekatan dalam tulisan ini bersifat library research dengan deskriptif kualitatif, pengumpulan data dilakukan melalui sumber-sumber yang tidak lansung. Dalam hal ini menurut Sugiyono (2011) Sumber data yang tidak

${ }^{5}$ Praherdhiono, Henry, Media Pembelajaran, Pembelajaran Berbasis Web; Sebagai Pendekatan Media Pembelajaran dalam Paradigma Konstruktivisme, Makalah Presentasi Prapasca S3 TEP UM Malang, 2017, hlm. 16-17. hlm. 496.

${ }^{6}$ Yusufhadi Miarso, Menyemai Benih Tekhnologi Pendidikan, Jakarta: Kenacana, 2007, 


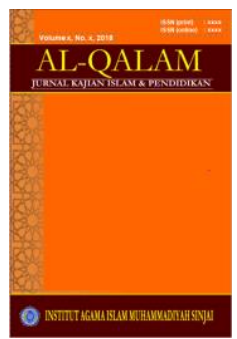

langsung memberikan data kepada pengumpul data, misalnya melalui dokumentasi ${ }^{7}$ Penulis melalukan dengan metode orientasi bacaan pada berbagai sumber-sumber yang dinilai tepat, baik dari buku-buku, jurnal terakreditasi, makalah, maupun literatur yang betrsifat (online dan offline). Sedangkan analisisnya menggunakan model Miles and Huberman melalui reduksi data(reduction), penyajian data(display), dan penarikan kesimpulan atau verifikasi (coclusion, ferification). ${ }^{8}$

\section{KERANGKA TEORI}

\section{A. Konstruktivisme sebagai Teori Belajar Modern}

Konstruktivisme sebagai salah satu aliran dalam filsafat pendidikan, Von Glaserveld dalam Battencourt (1989), Mattews (1994) dan Baedhowi, (2015) pernah mengingatkan konstruktivisme "menegasikan bahwa pengetahuan kita sesungguhnya merupakan hasil konstruksi atau bentukan kita sendiri". 9 Pemikiran ini berarti bahwa manusia memiliki kemampuan dalam membentuk makna-makna melalui peran pengalaman. Demikian yang dikembangkan diantaranya oleh Piaget dan Vygotsky, sebagai suatu konstruksi teori belajar, dimana Piaget mengemukakan jika individu prosesnya membentuk makna dari dalam dirinya sementara Vygotsky menilai individu membentuk makna dari proses interaksi sosial.

Dewey (1916, 1944a, 1944b)dalam Praherdhiono (2017) berpendapat bahwa peran pengalaman dalam belajar penting bagiperspektif konstruktivisme adalah ketika kita mengalami sesuatu yang dilakukan,maka akan melakukan sesuatu dengan itu. Pengalaman seperti mencobamelibatkan perubahan, tapi perubahan adalah transisi tanpa makna kecuali jikadikaitkan

\footnotetext{
${ }^{7}$ Sugiyono, Metode Penelitian Pendidikan; Pendekatan Kuantitatif, Kualitatif dan R\&D (Bandung: Alfabeta, 2011), hlm. 193. 1984).t.h

${ }^{8}$ Milles, M.B. and Huberman,, M.A,Qualitative Data Analysis. London: Sage Publication,

${ }^{9}$ Baedhowi, Ahmad, dkk, Potret Pendidikan Kita, (Jakarta: PT. Pustaka Alvabet, 2015), hlm. 14 .
} 


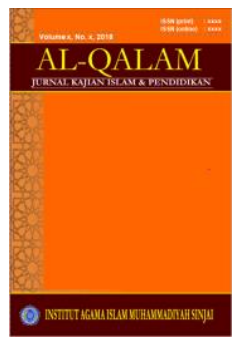

AL-QALAM

Jurnal Kajian Islam \& Pendidikan

Volume 9, No. 1, 2017

ISSN (print) : 1858-4152

ISSN (online) : xxxx-xxxx

Homepage : http://journal.iaimsinjai.ac.id/index.php/al-qalam

secara sadar sebagai konsekuensi yang mengalir darinya. Ketika sebuahaktivitas berlanjut ke dalam proses konsekuensi, maka ketika perubahan yangdilakukan oleh tindakan dipantulkan kembali kedalam perubahan yang terjadi didalam diri kita, maka disebut belajar sesuatu. ${ }^{10}$

Pembentukan makna dalam konteks pembelajaran adalah bahwa pelajar menciptakan atau membangun pembelajaran mereka sendiri. Asumsi lain konstruktivis adalah bahwa guru tidak boleh mengajar secara tradisional. ${ }^{11}$ Reigeluth \& Cheliman berujar peran guru berubah dari "sage on the stage" menjadi "guide on the side". ${ }^{12}$ Oleh karena itu pembelajaran harus dirancang untuk memudahkan pengetahuan individu, konstruksi dengan membantu peserta didik melakukan tugas otentik dan bermakna. ${ }^{13}$

Premis inti konstruktivisme adalah proses kognitif (termasuk pemikiran dan belajar) berada (terletak) dalam konteks fisik dan sosial. Sehingga rekomendasi yang paling mudah adalah melibatkan siswa secara aktif dalam pembelajaran mereka dan untuk memberikan pengalaman yang menantang pemikiran dan kekuatan mereka. Dalam lingkungan konstruktivis, penilaian terjadi terus menerus selama pengajaran baik siswa maupun guru. ${ }^{14}$ Penemuan makna baru secara eksploratif merupakan hakikat pembelajaran konstruktif yang bermuara pada kualitas yang bermakna.Kualitas bermakna menurut Jonassen (1995) dalam Setyosari \& Praherdhiono meliputi; aktif, konstruktif, kolaboratif, konversasional, kontekstual dan reflektif. ${ }^{15}$ Kaitan ini Derry (1996) dalam Schunk berpendapat

\section{${ }^{10}$ Praherdhiono, Media...hlm.2}

${ }^{11}$ Schunk, Dale H., Learning Theories, An Educational Perspective, Sixth Edition.6th,2012, ed.p.cm, hlm. 231.

12 Charles, M. Reigeluth,.\& Alison A. Carr-Chellman.(Eds.).Instructional-Design Theories and Models.A. New Paradigm Of Instrucctional Theory,(Volume II). Routledge.New York: Taylor and Francis Publishers, 2009,t.h.

${ }_{13}$ Charles, M. Reigeluth,.\& Alison A. Carr-Chellman,.(Eds.). Instructional-Design Theories and Models The Learner Centered Paradigm of Education, (Volume IV). Routledge.New York: Taylor and Francis Publishers, 2017, hlm.17.

${ }^{14}$ Schunk, Dale H., Learning...hlm.233.

${ }^{15}$ Setyosari, Punaji, \& Praherdhiono, Henry. Teori dan Aplikasi; Sistem Online dalam Pembelajaran, (Malang; FIP Universitas Negeri Malang, 2006), hlm.21. 


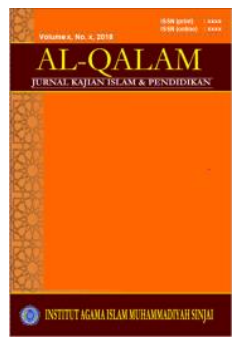

Volume 9, No. 1, 2017

ISSN (print) : 1858-4152

ISSN (online) : xxxx-xxxx

Homepage : http://journal.iaimsinjai.ac.id/index.php/al-qalam

bahwabanyak prinsip, konsep, dan gagasan yang mencerminkan gagasan konstruktivisme, termasuk pemrosesan kognitif, harapan, nilai, dan persepsi diri dan orang lain. ${ }^{16}$

\section{B. Pembelajaran PAI di Era TIK}

Pembelajaran adalah suatu usaha yang disengaja, bertujuan dan terkendali agar orang lain belajar atau terjadi perubahan yang relatif menetap pada diri orang lain. Usaha ini dilakukan oleh seseorang atau suatu tim yang memiliki kemampuan dan kompetensi dalam merancang dan atau mengembangkan sumber belajar yang diperlukan. ${ }^{17}$ Menurut Ahmad Patoni pembelajaran adalah untuk membelajarkan peserta didik. Definisi ini mengandung makna bahwa dalam pembelajaran tersebut ada kegiatan memilih, menetapkan dan mengembangkan metode/strategi yang optimal untuk mencapai hasil pembelajaran yang dinginkan dalam kondisi tertentu. ${ }^{18}$ Pandangan tersebut menegaskan bahwa pembelajaran PAI adalah proses membelajarkan individu dengan nilai-nilai ajaran Islam sehingga dapat menjadi way of life dalam kehidupan individu pembelajar sekaligus goal akhir yakni learning to think, learning to do, learning to be, learning to live together.

Mengingat pembelajaran PAI diera kemajuan ICT selain efektif menunjang pembelajaran juga penting merespon kemajuannya teknologi informasi yang membawa pengaruh buruk atas penggunaan teknologi yang bukan pada asas kebermanfaatan. Dengan perkembangan ICT yang sulit terkendali tentu pembelajaran PAI dinilai berandil dalam memfilter dekandesi moral bahkan dehumanisasi dalam masyarakat. Respon atas demikian dalam pandangan Abd. Aziz (2009) PAI dapat memberikan andil yang maksimal

\footnotetext{
${ }^{16}$ Schunk, Dale H., Learning...

${ }^{17}$ Yusufhadi Miarso, Menyemai.,hlm. 545.

18 Ahmad Patoni, Metode Pembelajaran Agama Islam, (Yogyakarta:Gre Publishing,
} 2012), hlm.198. 


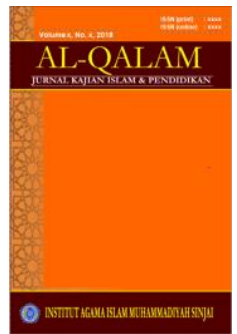

AL-QALAM

Jurnal Kajian Islam \& Pendidikan

Volume 9, No. 1, 2017

ISSN (print) : 1858-4152

ISSN (online) : xxxx-xxxx

Homepage : http://journal.iaimsinjai.ac.id/index.php/al-qalam

dalam pembentukan jiwa dan kepribadian adalah pendidikan yang mengacu pada pemahaman ajaran yang baik dan benar, mengacu pada pemikiran yang rasional dan filosofis, pembentukan akhlak yang luhur dan merehabilitasi kehidupan akhlak yang telah rusak. ${ }^{19}$ Oleh karena itu inti dari pembelajaran PAI adalah pembelajaran memiliki muatan-muatan nilai positif dalam kehidupan.

Pada proses pembelajaran PAI umumnya menggunakan model Direct Instuction yang menekankan penguasaan materi dan perubahan prilaku yang bersifat deduktif, maka pengetahuan yang dipahami oleh siswa akan sesuai dengan materi yang diajarkan maupun merekonstruksi prilaku sebagai indikator hasil pembelajaran. Joyce (2016) menilai jika ahli psikologi behavioral lebih membahas interaksi antara guru dan murid, mereka lebih membicarakan mengenai modeling, penguatan reinforcement, respon balik (feedback) dan perkiraan suksesif (succesif approximation). ${ }^{20}$ Secara garis besar situasi model direct incstruction dalam pembelajaran PAI peran guru cenderung; (1). Memperkenalkan dan menunjukkan keterkaitan konsep prinsip dan garis besar materi. (2). Penunjukan keterampilan, sikap dan argumentasi diajarkan dengan struktur yang jelas dan harus didasarkan bukti empiris. (3). Problem solving harus melalui penjelasan yang terstruktur. (4). Dalam suatu teknik dan prosedur ditunjukkan melalui praktek guru. (5). Menumbuhkan ketertarikan belajar ditentukan melalui suatu topik. (6). Penilaian melalui indikator penguasaan materi dan sikap pada suatu aktivitas

\section{Pendidikan di Era Big Data}

Pembelajaran berbasis ICT telah diakui memiliki kontribusi dalam berbagai inovasi bahkan dalam menjawab pergeseran paradigma ke era Big

\footnotetext{
${ }^{19}$ Abd,Aziz, Filsafat Pendidikan Islam, Sebuah Gagasan Membangun Pendidikan Islam, (Yogyakarta: Teras, 2009), hlm. 143,

${ }^{20}$ Joyce, B., Weil, M. \& Calhoun,.Models of Teaching (Ninth Edition). Terjemahan Rianayati Kasmini Pancasari, (Yogyakarta: Pustaka Pelajar. Allyn and Bacon, 2016), hlm.548.
} 


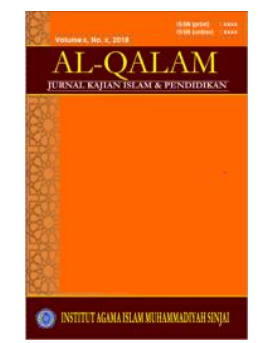

AL-QALAM

Jurnal Kajian Islam \& Pendidikan

Volume 9, No. 1, 2017

ISSN (print) : 1858-4152

ISSN (online) : $\mathrm{xxxx}-\mathrm{xxxx}$

Homepage : http://journal.iaimsinjai.ac.id/index.php/al-qalam

Data saat ini akan jauh lebih membangkitkan pandangan optimis tentang ketersediaan data informasi dalam kebutuhan pembelajaran dimasa yang akan datang. Boyd, D. \& Crawford, K. (2012) dan Jou, S. (2014) dalam Hapnes Toba (2015) mengemukakan secara umum big data dapat diartikan sebagai sebuah kumpulan data yang berukuran sangat besar(volume), sangat cepat berubah/(velocity), hadir dalam beragam bentuk/format (variety), serta memiliki nilai tertentu (value), dengan catatan jika berasal dari sumber yang akurat (veracity). Manyika, J (2011) juga menambahkan hal utama yang membedakan bigdata dengan kumpulan data konvensional terletak pada mekanisme pengelolaannya. Sistembasis data relasional yang saat ini umum digunakan, sudah dirasakan tidak mampu menangani kompleksitas big datas ecaraoptimal. $^{21}$

Karakterisasi Big Data telah berkembang sejak istilah tersebut diciptakan dalam literatur sains komputer pada tahun 1997 untuk merujuk pada data yang terlalu besar untuk disimpan dalam sistem penyimpanan konvensional. ${ }^{22} \mathrm{Big}$ data merupakan kumpulan data besar dan kompleks yang tak memungkinkan lagi untuk dikelola dengan tools software tradisional. Terdapat dua tipe teknologi untuk memberdayakan Big data, yaitu: (1) teknologi untuk memproses Big Data demi kebutuhan operasional, yakni: database NoSQL (MongoDB, HBase,...), dan (2).teknologi untuk memproses Big Data guna kebutuhan analitis seperti halnya Hadoop. Dengan mengimplementasikan kedua type teknologi Big Data ini, memungkinkan didapatkannya nilai-nilai baru yang dapat memberikan manfaat. ${ }^{23}$

\footnotetext{
${ }^{21}$ Hapnes Toba,Big Data: Menuju Evolusi Era Informasi Selanjutnya, Paper Conference, Bandung, Fakultas Teknologi Informasi Universitas Kristen Maranatha, 2015, hlm. 1

${ }^{22}$ Lebih lanjut lihat, Stephen J Mooney, Daniel J Westreich, \&Abdulrahman M El-Sayed, Epidemiology in the Era of Big Data, (2015), Department of Epidemiology, Mailman School of Public Health, Columbia University, Gillings School of Public Health, University of North Carolina, HHS Public AccessEpidemiology. Author manuscript, hlm. 1, lihat juga https://www.ncbi.nlm.nih.gov.

${ }^{23}$ W. Jaya, Apa Itu Big Data, (2016) lihat dalam website, https://www.kompasiana.com, diakses 6/10/2017
} 


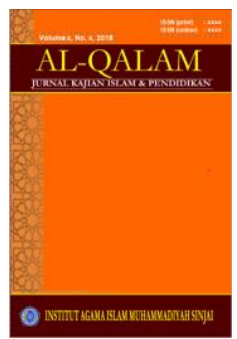

AL-QALAM

Jurnal Kajian Islam \& Pendidikan

Volume 9, No. 1, 2017

ISSN (print) : 1858-4152

ISSN (online) : $\mathrm{xxxx}-\mathrm{xxxx}$

Homepage : http://journal.iaimsinjai.ac.id/index.php/al-qalam

Saida Ulfa (2017) mencontohkan pengguna perangkat teknologi mobile yang cukup tinggi berakibat pada perkembangan dan menghasilkan data. Hampir setiap orang saat menggunakan perangkat digital dan menghasilkan data, bahkan setiap menit sekitar 48 jam konten video di upload ke youtube, 2 juta pencarian di lakukan di google, sekitar 100 ribu tweets diciptakan dan semua ini tersimpan dalam bentuk data. Setiap saat terjadi pertukaran data yang besar dan cepat.Hasil penelitian yang dilakukan IBM, diprediksi pada tahun 2020, setiap orang akan menghasilkan data sekitar 5200 gigabytes. Bisa dibayangkan bagaimana menyimpan keseluruhan data tersebut yang akan menciptakan ekosistem digital yang besar. ${ }^{24}$ Dengan mengingat begitu luasnya sumber yang tersedia, jika Big Data hanya dipandang sebagai suatu kumpulan data saja, maka tidak akan menghasilkanin formasi apapun. Untuk dapat menghasil kaninformasi dari Big Data, diperlukan adanya analisis yang mendalam, misalnya melalui pemodel anmatematis. ${ }^{25}$

Perkembangan teknologi baru di era Big Data ini berkontribusi dalam bidang pendidikan khususnya dalam evolusi pembelajaran berbasis online (daring). Prospek "big data" sekaligus membangkitkan pandangan optimis tentang masa depan yang kaya informasi. Era ini menjanjikan para guru dan peserta didik tentang pembelajaran yang dipersonalisasi (personalized learning), penilaian formatif yang responsif dan pembelajaran kolaboratif. Hal ini sesuai dengan karakteristik Generasi di abad 21 saat ini, yaitu generasi Z yang tumbuh dan berkembang di era teknologi sehingga mereka dijuluki "digital natives", dan generasi sebelumnya dijuluki generasi "digital imigrants".Cope (2012) mendefinisikan "Big Data" dibidang pendidikan sebagai pencatatan terhadap kegiatan dan interaksi dalam media digital, dan kejadian di lingkungan pembelajaran interkoneksi yang dimediasi secara digital, beragam jenis data yang dapat dianalisis, aksesbilitas dan durasi waktu

\footnotetext{
${ }^{24}$ Saida Ulfa dan Deddy B. Lasfeto, Pendidikan...

${ }^{25}$ Lihat lebih lanjut, Hapnes Toba,Big Data...hlm.2
} 


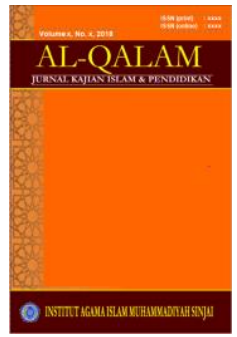

AL-QALAM

Jurnal Kajian Islam \& Pendidikan

Volume 9, No. 1, 2017

ISSN (print) : 1858-4152

ISSN (online) : $\mathrm{xxxx}-\mathrm{xxxx}$

Homepage : http://journal.iaimsinjai.ac.id/index.php/al-qalam

untuk; (a). Penilaian formatif atau pengajaran yang adaptif, dan (b). Mengembangkan profil pembelajar. ${ }^{26}$

\section{HASIL PEMBAHASAN}

\section{Pembelajaran PAI dalam Paradigma Konstruktivisme, Dari Berbasis}

\section{ICT ke Era Big Data; Peluang dan Tantangan}

Sebagai pendekatan berorientasi Learning Teacher Centered (TCL) berparadigma behavioristik model ini dinilai bahwa informasi dan pengetahuan masih bersumber dan terpusat pada guru sehingga indikator keterampilan dan pengetahuan terlihat pada siswa yang menguasainya. Dalam hal tertentu tidak semua dalam proses pembelajaran dan fase perkembangan siswa tidak cukup dibentuk secara direct instructionseperti karakter kepatuhan, toleransi, kejujuran, pembelajaran yang merubah sikap siswa dalam pembelajaran PAIyangjustru lebih menekankan role model.

Selain model direct instruction dalam pembelajaran PAI pendekatan konstruktivisme dinilai sebagai suatu pengembangan yang memungkinkan siswa mengembangkan pembelajarannya dengan cara membentuk pengetahuan dan makna baru dengan berdasar pada pengalaman atau model dari guru. Pembelajaran berbasis ICT dan Big Data dalam konteks paradigma konstruktivisme ini guru sebagai fasilitator dapat mendorong siswa pada upaya membentuk makna-makna baru melalui pembelajaran terpusat pada learner center secara online connected eksploration. Praherdhiono (2017) menyebutnya (pengajar terhadap pembelajar) mencoba mengetahui konstruksi berpikir, sehingga pebelajar bisa membangun makna secara bersama. Kenyataan berpikir mahapebelajar adalah terbuka terhadap proses kreasi. Sampai tingkat tertentu, pengajar hanya dapat mempengaruhi kemauan pebelajar untuk belajar, walaupun sebagian besar secara intrinsik dapat

\footnotetext{
${ }^{26}$ Saida Ulfa dan Deddy B. Lasfeto, Pendidikan...
} 


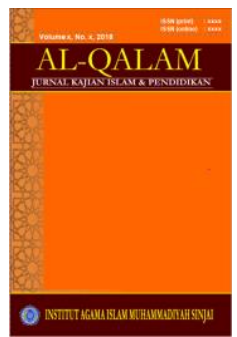

AL-QALAM

Jurnal Kajian Islam \& Pendidikan

Volume 9, No. 1, 2017

ISSN (print) : 1858-4152

ISSN (online) : $\mathrm{xxxx}-\mathrm{xxxx}$

Homepage : http://journal.iaimsinjai.ac.id/index.php/al-qalam

dimotivasi. ${ }^{27}$ Maka untuk membantu siswa dalam tindakan berpikir dan proses kreasi itulah pendidik/guru dapat menfasilitas dengan memberikan pengalaman melalui alternatif media digitalisasi baik website, sosial media yang menyuguhkan ragam informasi yang dibutuhkan. Sebagai contoh materi pelajaran Al-Quran Hadits, Fiqih, materi ibadah dapat dikembangkan siswa melalui eksploratif berbasis media digital web, sosial media, youtube (video) dll dengan pilihan materi pembelajaranyang beragam.

Jika siswa (learner) yang tumbuh sebagai generasi $\mathrm{Z}$ dalam pandangan Saida Ulfa (2017) memiliki karakteristik sebagai generasi yang "terhubung" (connected), "terpelajar" (educated) dan cerdas. Karena tumbuh di lingkungan berbasis teknologi, dimana teknologi memberikan peluang untuk mengakses informasi dan interaksi sosial tanpa henti, yang pastinya berpengaruh pada gaya berpikir dan belajarnya. ${ }^{28}$ Kaitannya dalam proses pembelajaran lebih lanjut menurutnya ini akan berimbas pada perubahan paradigma pembelajaran, yakni dari berpusat pada instruktur (Teacher Centered Learning) menjadi pembelajaran berpusat pada peserta didik (Student Centered Learning). Sehingga pendekatan Student Centered ini dirancang lebih fleksibel namun kompleks.Pembelajaran tidak lagi hanya terikat pada waktu dan ruang, pembelajaran dapat dirancang untuk dapat diakses kapan dan dimanapun dengan memanfaatkan media teknologi. Selain itu, hal yang menjadi fokus utama dalam pembelajaran abad 21 ini adalah bagaimana generasi "digital native" ini mampu mencapai kompetensi abad 21 yaitu kemampuan berpikir kritis dan menyelesaikan persoalan, kreativitas, keterampilan berkomunikasi, dan kemampuan untuk berkolaborasi dengan orang lain. ${ }^{29}$ Dengan demikian output dari pembelajaran PAI akan terlihat dengan memiliki kemampuan kompetensi abad 21 yang berkarakter nilai.

\footnotetext{
${ }^{27}$ Praherdhiono, Media...hlm.4

${ }^{28}$ Saida Ulfa dan Deddy B. Lasfeto, Pendidikan...

${ }^{29}$ Saida Ulfa dan Deddy B. Lasfeto, Pendidikan...
} 


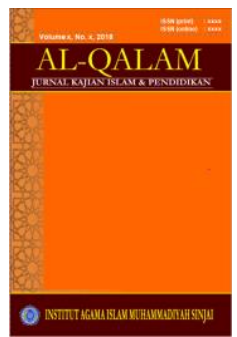

AL-QALAM

Jurnal Kajian Islam \& Pendidikan

Volume 9, No. 1, 2017

ISSN (print) : 1858-4152

ISSN (online) : xxxx-xxxx

Homepage : http://journal.iaimsinjai.ac.id/index.php/al-qalam

Peluang ini dapat direspon dengan mempersiapkan kompetensi pendidik secara berkualitas (educator high quality)serta keterampilan digitalisasi yang harus selalu terasahhingga benar-benar mampu dan siap membelajarkan peserta didik. Era ICT dan era Big Data dengan cakupan cukup luas juga memberikan tantangan yang kompleks bagi pendidik/guru dalam pembelajaran yang konstruktif dan transformatif. Selain itu tantangan guru sebagai alasan dalam pedagogi konstruktivis ini menurut Brooks \& G. Brooks (1999) adalah komitmen terhadap pendekatan instruksional mereka saat ini, kekhawatiran tentang pembelajaran siswa, dan kekhawatiran tentang pengendalian kelas. Pendekatan konstruktivis terhadap pengajaran akan mengikis sebagian kendali mereka/guru. ${ }^{30}$

Tantangan kompleks dari era ICT bahkan era Big Data ini bagi peserta didik adalah penggunaan teknologi dengan akses tak terbatas mengakibatkan pemanfaatan menjadi tidak selayaknya sesuai tujuan pembelajaran sehingga tetap dibutuhkan kontrol secara bijak. Sedangkan prinsip penting pendidikan diera digitalisasi ICT dan Big Data pada pembelajaran berparadigma konstruktivis adalah terwujudnya peserta didik "good online learner" yang akan menuju pada "future learner"yang responsif, kolaboratif yang hight quality. Dalam kaitan ini menurut Saida Ulfa ${ }^{31}$ bahwa Big Data menangkap kemungkinan untuk lebih memahami pembelajaran individu dan kelompok karena terhubung dalam kerangka komputasi interpersonal yang kedepannya tercipta sebuah kerangka lingkungan belajar berbasis pintar Smart Learning Environtment (SLE).

Setyosari \& Praherdhiono memandang bahwa proses belajar pada dasarnya adalah interaksi dialogis antara pebelajar, pembelajar, pebelajarpebelajar, pelajar dengan lingkungannya. Proses interaksi yang bersifat timbal

\footnotetext{
${ }^{30}$ Brooks, G. J dan Martin G. Brooks, M. G, (1999), Becoming a Contructivist Teacher, dalam website, http://www.ascd.org. diakses, 23/9/2017.

${ }^{31}$ Saida Ulfa dan Deddy B. Lasfeto, Pendidikan...
} 


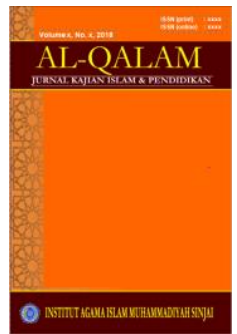

AL-QALAM

Jurnal Kajian Islam \& Pendidikan

Volume 9, No. 1, 2017

ISSN (print) : 1858-4152

ISSN (online) : $\mathrm{xxxx}-\mathrm{xxxx}$

Homepage : http://journal.iaimsinjai.ac.id/index.php/al-qalam

balik. ${ }^{32}$ Lebih lanjut dikemukakan bahwa untuk memperoleh pengalaman nyata dan menghubungkan dengan dunia yang terus berkembang, pembelajaran harus menekankan perkembangan pebelajar dan belajar diarahkan ke hal yang lebih bermakna (meaningfulness). ${ }^{33}$ Dalam paradigma konstruktifjika kaitan menemukan makna dalam ranah afektif tentu menimbulkan pertanyaan bahwa mungkinkah dalam pembelajaran PAI peranan guru dapat berubah dengan berparadigma konstruktivis?, Sedangkan paradigma behavioralis dalam ranah afektif (sikap, nilai, dan prilaku) peserta didik justru ditekankan pada kemampuan mereproduksi prilaku. Oleh karena itu dalam pembelajaran berbasis ICT dan diera Big data pendidik/guru hendaknya memiliki pengetahuan, pengalaman, penguasaan materi dan keragaman model yang cukup sehingga dapat menyeimbangkan ranah dan fase perkembangan peserta didik, menyesuaikan pengetahuan yang diterima menuju pada pengetahuan baru (konstruktivis).

Pada prinsipnya guru punya keyakinan bahwa perannya lebih dari sekedar transmiter pembelajaran dan pembelajar yakni fasilitator sebagai perancah, model, pelatih dan pembimbing. Disamping sebagai fasilitator peranan guru secara spesifik adalah sebagai axpert learners,manager and expert teacher, mediator. (1). Sebagai expert learners, diperlukan memiliki pemahaman dan kemampuan mendalam tentang materi pembelajaran, mampu menyediakan waktu, masalah dan alternatif solusi, mampu mencapai tujuan kognitif, metakognitif, afektif, dan psikomotor siswa. (2). Sebagai manager dan expert teacher,mampu memonitor hasil belajar dan perkembangannya, disiplin kelas dan hubungan interpersonal, serta menyeleksi proses-proses kognitif untuk mengaktifkan pengetahuan siswa. (3). Sebagai mediator, guru memandu antar siswa, membantu memformulasikan pertanyaan atau mengkonstruksi makna suatu masalah, mengembangkan sikap positif belajar, pemusatan perhatian,

\footnotetext{
${ }^{32}$ Setyosari, Punaji, \& Praherdhiono, Henry. Teori..hlm.21.

${ }^{33}$ Setyosari, Punaji, \& Praherdhiono, Henry. Teori..hlm.14.
} 


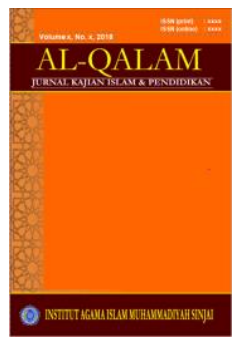

mengaitkan informasi baru dengan pengetahuan awal maupun gagasan siswa, pemodelan proses berpikir kritis. Dalam desain pembelajaran ini peran guru adalah menciptakan dan memahami sintaks sehingga mempermudah implementasi pembelajaran. Jika dalam prinsip konstruktivisme maka sintaks pembelajaran akan mengalami adaptasi kebutuhan yang rekursif, fleksibel, dan dinamis. ${ }^{34}$

Menurut Baedhowi (2015) guru dan siswa dapat secara bersama-sama mengkonstruksi skema kognitif, kategori, konsep dan struktur dalam membangun pengetahuan sehingga setiap bangunan proses belajar mengajar memiliki skema kognitif, kategori, konsep dan struktur yang lebih kaya dan berbeda. ${ }^{35}$ Beetleston (2012) menyarankan guru dapat mengadopsi berbagai pendekatan terhadap pembelajaran yang akan mendorong menyelesaikan masalah dan investigasi, membangkitkan keingintahuan alamiah anak-anak untuk belajar. ${ }^{36}$ Guru dan peserta didik dapat memilih, menemukan dan menyusun pengetahuan, mengembangkanketrampilannya (method of inquiry anddiscovery)serta memonitor dan mengevaluasi hasil belajar. Jika konsep pembelajaran berbasis digitalisasi ICT dan di era Big Data ini dapat dipahami oleh guru maka upaya desain pembelajaran sangat mungkin terwujud dan menantang.

\section{KESIMPULAN}

Pembelajaran PAI dalam paradigma konstruktivisme dalam pendekatan berbasis media digitalisasi ICT dan diera Big Data tidak lain untuk menunjang proses pembelajaran yang lebih bermakna melalui penemuan informasi dan data yang dibutuhkan oleh pendidik dan peserta didik serta dapat mendukung pembentukan karakternya sesuai ajaran Islam, terwujudnya peserta didik yang "good online learner", learner hight quality. Bermanfaat dalam kebutuhan

${ }^{34}$ Alimsumarno, Peran Guru dalam Pembelajaran Konstruktivistik, 2011, dalam website http:// alimsumarno.blog.unesa.ac.iddi akses, 22/9/2017

${ }^{35}$ Ahmad Baedhowi dkk, 2015, Potret...hlm.14

${ }^{36}$ Ahmad Baedhowi dkk, 2015, Potret... 


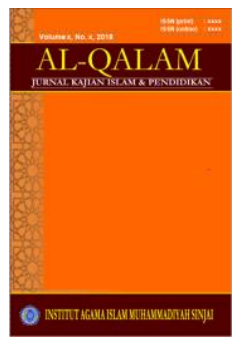

AL-QALAM

Jurnal Kajian Islam \& Pendidikan

Volume 9, No. 1, 2017

ISSN (print) : 1858-4152

ISSN (online) : $\mathrm{xxxx}-\mathrm{xxxx}$

Homepage : http://journal.iaimsinjai.ac.id/index.php/al-qalam

hidupnya serta mengantarkan pada keharmonisan yang berkelanjutan. Oleh karena itu sudah selayaknya pendidik dan peserta dapat selalu diperkenalkan kemajuan teknologi berbasis digitalisasi ICT dan di era Big Data ini. Oleh karena itu seiring perkembangan inovasi teknologi juga pembelajaran dalam pendidikan agama Islam juga perlu senantiasa diinovasi.

Era Big Data merupakan suatu peluang yang dapat meningkatkan kualitas pendidikan khususnya output pendidikan agama Islam. Paradigma baru ini sebagai suatu evolusi media pembelajaran berbasis ICT tepat untuk selalu disikapi dalam aspek pembelajaran peserta didik, dimana Big Data dapat menjadi pintu masuk bagi kalangan educated and learner dalam memanfaatkan data yang melimpah. Oleh karena itu pembelajaran PAI dapat ditunjang oleh ketersediaan data dan informasi bermanfat dari domain digitalisasi (ICT ) dan Big Data. Pemanfaatan ini diharapkan pada orientasi pembelajaran berkualitas yakni pembentukan nilai-nilai yang selaras dengan ajaran Islam sehingga terbangun harmonisasi yang seimbang.

\section{DAFTAR RUJUKAN}

Aziz,Abd, Filsafat Pendidikan Islam, Sebuah Gagasan Membangun Pendidikan Islam, Yogyakarta: Teras, 2009.

Baedhowi, Ahmad dkk, Potret Pendidikan Kita, Jakarta: PT. Pustaka Alvabet, 2015.

Brooks, G. J dan Martin G. Brooks, M. G, Becoming a Contructivist Teacher, (1999), dalam http://www.ascd.org/publications/books/199234/chapters/Becoming-aConstructivist Teacher.aspx, diakses, 23/9/2017.

Https://www.ncbi.nlm.nih.gov.

Huberman, M.A, and MB, Miles, Qualitative Data Analysis. London: Sage Publication, 1984. 


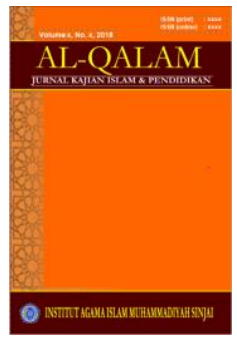

\section{AL-QALAM}

Jurnal Kajian Islam \& Pendidikan

Volume 9, No. 1, 2017

ISSN (print) : 1858-4152

ISSN (online) : $\mathrm{xxxx}-\mathrm{xxxx}$

Homepage : http://journal.iaimsinjai.ac.id/index.php/al-qalam

Ine, Era Big Data dan Era Inovasi, 2017, dalam https://beritabigdata.wordpress.com/support/era-big-data-era-inovasi/, diakses, 10/6/2017.

Jaya, W. Apa Itu Big Data, Menyimak Kembali Definisi Big Data, Jenis Teknologi Big Data dan Manfaat Pemberdayaan Big Data, 2016,. dalam https://www.kompasiana.com/wmwijaya/, diakses, 6/10/2017.

Joyce, B., Weil, M. \& Calhoun,.Models of Teaching (Ninth Edition). Terjemahan Rianayati Kasmini Pancasari, Yogyakarta: Pustaka Pelajar. Allyn and Bacon, 2016.

Kominfo, Pengguna Internet Indonesia Nomor Enam Dunia, 2014. dalam .https://kominfo.go.id/_content/detail/4286/pengguna-internetindonesia-nomor-enam-dunia/0/sorotanmedia 2014. Diakses 6/10/2017.

Mooney, J. Stephen, Westreich, J. Daniel, \& El-Sayed, M. Abdulrahman, Epidemiology in the University, Gillings School of Public Health, University of North Carolina Era of Big Data,Department of Epidemiology, Mailman School of Public Health, Columbia, HHS Public AccessEpidemiology. Author manuscript. 2015.

Miarso, Yusufhadi,Menyemai Benih Tekhnologi Pendidikan, Jakarta: Kenacana, 2007.

Patoni,Ahmad.Metode Pembelajaran Agama Islam, Yogyakarta:Gre Publishing, 2012.

Praherdhiono, Henry, Media Pembelajaran, Pembelajaran Berbasis Web; Sebagai Pendekatan Media Pembelajaran dalam Paradigma Konstruktivisme, Makalah Presentasi Prapasca S3 TEP Universitas Negeri Malang, 2017.

Reigeluth, Charles M. \& Carr-Chellman, Alison A.(Eds.).Instructional-Design Theories and Models (Volume III): Building a Common Knowledge Base. Routledge.New York: Taylor and Francis Publishers, 2009.

Reigeluth, Charles M. \& Carr-Chellman, Alison A.(Eds.).Instructional-Design Theories and Models The Learner Centered Paradigm of Education, (Volume IV). Routledge.New York: Taylor and Francis Publishers, 2017. 


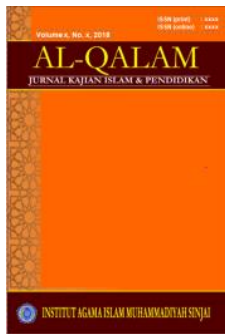

AL-QALAM

Jurnal Kajian Islam \& Pendidikan

Volume 9, No. 1, 2017

ISSN (print) : 1858-4152

ISSN (online) : xxxx-xxxx

Homepage : http://journal.iaimsinjai.ac.id/index.php/al-qalam

Schunk, Dale H., Learning Theories, An Educational Perspective, Sixth Edition.6th, ed.p.cm, 2012.

Setyosari, Punaji, \& Praherdhiono, Henry. Teori dan Aplikasi; Sistem Online dalam Pembelajaran, Malang; FIP Universitas Negeri Malang, 2006.

Sugiyono, Metode Penelitian Pendidikan; Pendekatan Kuantitatif, Kualitatif dan $R \& D$ Bandung: Alfabeta, 2011.

Sumarno Alim, Peranan Guru dalam Pembelajaran Konstruktivistik, 2011. dalam http://alim sumarno.blog.unesa.ac.id/peranan-guru-dalampembelajaran-konstruktivistik,(2011), diakses, 22 /9/2017

Toba, Hapnes.Big Data: Menuju Evolusi Era Informasi Selanjutnya, Paper Conference,. Bandung, Fakultas Teknologi Informasi Universitas Kristen Maranatha,2015. Lihat Juga dalam https://www.researchgate.net/publication/274712686.

Tim APJII dalam,Infografis, Penetrasi dan Prilaku Pengguna Internet Indonesia, (APJII) Survey, 2016, dalam file pdf,

UlfaSaida \&Lasfeto, B.Deddy,Pendidikan di Era Big Data, (2017), dalam http://timorexpress. fajar.co.id/2017/05/05/pendidikan-di-era-bigdata/, diakses 6/10/2017. 